\title{
KETENTUAN PERUSAHAAN PERS WAJIB BERBADAN HUKUM PERSEROAN TERBATAS (PT) MERUPAKAN DOKTRIN HUKUM YANG BERBASIS HUKUM POSITIF
}

\section{Yusuf Ms}

Sekolah Tinggi Ilmu Hukum (STIH) IBLAM Jakarta, Indonesia

Email: yusuftheo@gmail.com

\begin{abstract}
Abstrak
Salah satu tuntutan reformasi 1998, adanya kebebasan pers, atau pendirian perusahaan pers tidak perlu menggunakan ijin dari pemerintah, karena hal itu akan menghambat nilai-nilai demokrasi. Lahirnya Pasal 9 ayat(1) dan (2) UU No 40 Tahun 1999 tentang Pers, yang memberikan kebebasan setiap warga negara dan negara untuk mendirikan perusahaan pers berbadan hukum Indonesia. Oleh karenanya, DP mengeluarkan Peraturan No 4/DP/III/2008 tentang Standarisasi Perusahaan Pers Jo.Surat Edaran No 1/SE DP/I/2014 tentang pelaksanaan UU pers dan Standarisasi perusahaan pers. Peraturan DP dimohonkan diuji materi ke MK, oleh salah seorang pimpinan penerbitan yang pada akhirnya ditolak karena tidak memenuhi aspek spesifikasi permohonan. Guna mendapatkan kesimpulan yang memadai, tulisan ini menggunakan metode penulisan yuridis normative-empiris, karena selain mengumpulkan buku ilmu hukum, jurnal dan peraturan perundangundangan yang terkait dengan tema itu. Untuk mendapatkan gambaran lengkap, Tulisan ini juga memasukkan Putusan MK. No. 51 Tahun 2018 atas permohonan dari seorang Direkur Swara Resi yang beralmat di Mekarsari Depok untuk dianalisa beserta bahan lainnya. Hasil dari penelitihan itu mendapatkan jawaban, Peraturan DP No 4/DP/III/2008 Jo. SE No 01/SE DP/I/2014 merupakan sebuah doktrin hukum yang dikuatkan oleh Putusan Mahkamah Konstitusi (MK) No 51/PUXVI/2018 yang pokok intinya menolak permohonan pemohon sehingga menjadi hukum positif. Dengan ditolaknya permohonan uji materi Peraturan DP dan SE DP, dapat disimpulkan, Dewan Pers sebagai lembaga negara dapat membuat peraturan perundang-undangan yang dikuatkan oleh Putusan MK, sehingga peraturan tersebut sebagai hukum positif yang mengikat kesemua warga negara Indonesia yang akan membuat usaha pers, yakni Perseroan Terbatas (PT) jika hal itu dimaknai sebagai usaha pers yang bersifat komersial.
\end{abstract}

Kata Kunci: Ketentuan Dewan Pers Perusahaan Wajib Berbadan Hukum; Pengujian Peraturan DP ke Mahkamah Konstitusi (MK)

\section{Abstract}

One of the demands for the 1998 reform, the existence of press freedom, or the establishment of a press company does not need to use a permit from the government, because it will obstruct democratic values. The birth of Article 9 paragraphs (1) and (2) of Law No. 40 of 1999 concerning the Press, which gives

$\begin{array}{ll}\text { How to cite: } & \text { Ms, Yusuf (2021) Ketentuan Perusahaan Pers Wajib Berbadan Hukum Perseroan Terbatas (PT) Merupakan } \\ & \text { Doktrin Hukum Yang Berbasis Hukum Positif. Syntax Literate: Jurnal Ilmiah Indonesia. 6(7). } \\ & \text { http://dx.doi.org/10.36418/ syntax-literate.v6i7.3660 } \\ \text { E-ISSN: } & \text { 2548-1398 } \\ \text { Published by: } & \text { Ridwan Institute }\end{array}$


freedom for every citizen and state to establish a press company with an Indonesian legal entity. Likewise Article 15 paragraph (1-7) which gives the role and function of the Press Council as a State institution has the right to make laws and regulations related to its main duties and functions. . Therefore, the DP issued Regulation No. 4 / DP / III / 2008 concerning Standardization of Press Companies Jo .. Circular Letter No. 1 / SE DP / I / 2014 concerning the implementation of the Press Law and Standardization of press companies. It is requested that the DP regulations be tested for material to the Constitutional Court, by one of the publishing leaders who in the end was rejected because they did not meet the specification aspects of the petition. In addition, DP regulations are considered to be general in nature or apply to every citizen and country that will establish a press company must be an Indonesian legal entity. In order to get an adequate conclusion, this paper uses the juridical normative - empirical writing method, because in addition to collecting books, journals and statutory regulations, it also analyzes the Constitutional Court Decision. No. 51 of 2018 at the request of a Swara Resi Director who has mercy in Mekarsari Depok. The results of the research got the answer, DP Regulation No 4 / DP / III / 2008 Jo. SE No. 01 / SE DP / I / 2014 is a legal doctrine that is strengthened by the Constitutional Court Decision No. 51 / PU-XVI / 2018 which basically rejects the petition of the applicant. With the rejection of the application for judicial review of the DP and SE DP Regulations, it can be concluded that the Press Council as a state institution can make laws and regulations that are strengthened by the Constitutional Court Decision, so that these regulations are positive laws that bind all Indonesian citizens who will make press efforts, namely Terbtas Company (PT) if it is interpreted as a commercial press business.

Keywords: Provisions for the Company Press Council; which must be a legal entity; examination of DP regulations to the Constitutional Court (MK)

\section{Pendahuluan}

Salah satu ciri negara demokrasi, antara lain memberikan ruang kebebasan terhadap proses hukum di pengadilan, sehingga keputusan hukum dilahirkan lewat proses yang independent tanpa ada pengaruh dan intervensi dari pemerintah atau kelompok di luar pengadilan. Selain itu masyarakat juga punya kebebasan untuk berkumpul, berserikat dan mengeluarkan pendapat lewat berbagai saluran salah satunya pers (Manan \& Harijanti, 2016).

Isyarat Indonesia sebagai negara demokrasi Pancasila yang terus berproses itu juga dapat dibaca dalam alinia ke empat pembukaan UUD 1945 yang dikonkritkan dalam Pasal 1 Undang-undang 1945 (Budiardjo, 2010).

Pembukaan adalah landasan filosofis, sementara pasal-pasal dalam UUD 1945 merupakan konkritisasi terhadap filsafat yang terkandung dalam pembukaan itu (Bo'a, 2020). Pasal 1 ayat (2) disebutkan, kedaulatan berada ditangan rakyat dan dilaksanakan menurut Undang-undang. Pengertian dari kalimat itu antara lain, semua yang dilakukan oleh pemerintah, perlu persetujuan raknyat lewat UU.

Penentuan kelembagaan pers di Indonesiapun juga ditentukan lewat UU No 40 Tahun 1999 tentang Pers. Pasal 9 menyebutkan: 
1) "Setiap waga negara Indonesia dan negara berhak mendirikan perusahaan pers.

2) Setiap perusahaan pers harus berbentuk badan hukum Indonesia."

Dengan demikian, negara memberikan hak kepada masyarakat untuk mendirikan perusahaan pers, dan negara-pun juga dapat mendirikan perusahaan pers. Oleh karenanya, baik masyarakat maupun negara dalam mendirikan perusahaan pers diatur oleh peraturan perundang-undangan guna meneguhkan, Indonesia sebagai negara hukum.

Hadirnya UU No 40 Tahun 1999, salah satu buah reformasi tahun 1998, dimana sebagian besar masyarakat menginginkan kebebasan pers dan pembuatan perusahaan pers, karena di masa Orde Lama dan Orde Baru, pembuatan perusahaan pers tidak semudah dibanding paska tahun 1999.

Oleh karenanya, Pasal 9 ayat 1 dan 2 sebagai jawaban atas tuntutan masyarakat pers yang telah lama menginginkan kebebasan dalam mendirikan perusahan pers. Namun keinginan kebebasan itu ternyata tidak mudah. Banyak pihak yang menginginkan pendirian perusahaan pers dapat dilakukan melalui badan usaha Comanditaire Venootshap/perseroan komanditer (CV), Yayasan, Koperasi, Perseroan Terbatas (PT), dan Perusahaan Umum (Perum) serta Lembaga Penyiaran Publik (LPP). Dewan Pers (DP) hanya menerima verifikasi perusahaan pers yang berbadan hukum PT jika hal itu untuk kepentingan publik.

Bella Resseina dkk menganalisis bahwa CV adalah lembaga usaha yang juga Lembaga berbadan hukum karena disahkan oleh otoritas hukum $\mathrm{Cq}$ Menkum Ham, meskipun pihak ketiga hanya diperbolehkan berhubungan dengan sekutu aktif, karena dinilai mempunyai tanggungjawab yang besar, yakni jika ada kerugian dalam berusaha, peserta aktif ikut bertanggung jawab atas kerugian itu.

Sementara sekutu pasif tidak dibebankan untuk menangung kerugian dari usahanya yang dijalankan pengurus komanditer, karena ia tidak melakukan hubungan dengan pihak ketiga. Sekutu komanditer pasif hanyalah mempercayakan modalnya kepada orang yang dipercaya yakni pengurus komanditer.

Oleh Ida Bagus Abhimantara, CV adalah sebagai lembaga usaha, tetapi tidak berbadan hukum, sehingga CV tidak dapat dijadikan sebagai penjamin utang kepada pihak ketiga atau tidak dapat bertindak lebih luas dalam menjalankan usahanya, karena tidak ditemukan unsur subeyktif dalam pasal 1320 BW (Abhimantara, 2019).

Setelah lahirnya UU No 40 Tahun 1999 tentang Pers, banyak usaha pers dengan badan hukum atau badan usaha CV, Yayasan dan PT karena salahsatu tuntutan reformasi mencabut ijin usaha pers dari Pemerintah Cq Departemen Penerangan.

Dengan dicabutnya ijin tersebut, perusahaan pers tumbuh besar bagaikan "bak jamur tumbuh dimusim penghujan". Dimana semua pihak rame-rame mendirikan perusahaan pers melalui CV, Yayasan, Koperasi dan PT karena mereka menilai Lembaga itu masih dalam bingkai Pasal 9 ayat (2) UU Pers.

Pasal 9 ayat (2) yang menyangkut soal "lembaga", oleh Dewan Pers dimaknai lembaga hukum Indonesia berbentuk Perseraon Terbatas (PT) jika hal itu sebagai usaha pers untuk kepentingan umum. Hal itu merupakan doktrin atau pendapat ahli berbasis 
hukum. Namun karena sudah mendapat pengakuan dari MK (lihat putusan No 51 Tahun 2018) maka doktrin tersebut kini sudah menjadi hukum positif.

Doktrin adalah pendapat seorang ahli hukum yang dapat dijadikan pijakan atau dalil oleh hakim untuk memutuskan sesuatu dan dapat diikuti oleh hakim berikutnya. Sedang hukum positif, hukum yang dibuat oleh lembaga perwalian rakyat/DPR bersama pemerintah, dan kemudian dilaksanakan untuk menciptakan kepastian, keteraturan dan keadilan. Namun banyak orang tidak puas, karena UU yang dihasilkan oleh lembaga resmi dinilai banyak cacat, seperti koruptif dan mengandung pesanan terhadap pasalpasal yang menguntungkan para pengusaha. Para ahli hukum berfikir agar para hakim tidak melaksanakan atau menggunakan hukum positif semata, jika ingin mendapat keadilan substantif. Tokoh hukum progresif, Satjipto Rahardjo yang menggagas, hukum progersif sebagai perlawan hukum positif yang statis dan tidak kreatif.

"Hukum progresif merupakan kegiatan aksi, bukan hanya pada tataran pelaksanaan peraturan. Orang masih dapat membantu mencari keadilan di luar dari mekanisme peraturan yang tersedia. Itulah gunanya para ahli hukum mereformasi dari hukum yang status qua, menjadi lebih kreatif dan bermartabat untuk manusia" (Faizal, 2016).

Animo masyarakat pers mendirikan perusahaan pers cukup antusias, sementara aturan dari Dewan Pers (DP) relatif ketat, sehingga menimbulkan konflik kepentingan. DP membuat tafsir Pasal 9 ayat (2) UU Pers, yakni hanya badan hukum PT yang dapat digunakan untuk usaha pers.

Sementara masyarakat pers masih ada yang menyakini, badan hukum seperti CV, Firna, Koperasi dan yayasan sebagai yang diatur melalui Undang-undang Hukum Dagang (WvK) sampai saat ini sebagai hukum positif, terbuka juga untuk usaha bidang pers. Ketentuan itulah yang membuat salah satu pemilik media web atau online dan media cetak di Lampung melakukan permohonan uji materi ke MK untuk membatalkan Peraturan yang dibuat DP khususnya peraturan No. 4/Peraturan DP/III/2008 tentang standari sasi perusahaan pers Jo. Surat Edaran No 01/DP/ I/2014 karena dinilai telah melanggar konstitusi khususnya Pasal 33 ayat (1) dan ayat (4), Pasal 27 ayat (2) dan Pasal 28D dan pasal 28F UUD 1945. Atas permohonan itu, MK Mengeluarkan Keputusan No 51/PUU-XIV/2018 yang pada intinya menolak gugatan oleh salah seorang pemlik perusahaan yang bergerak dibidang penerbitan, yang tidak menyebut perusahaan pers, sehingga dinilai layak untuk dijadikan studi kasus dalam membahas masalah kelembagaan pers.

\section{Metode Penelitian}

Perbedaan penafsiran tentang frasa lembaga berbadan hukum Indonesia dalam Pasal 9 ayat (2), oleh DP dengan penggugat, dapat didekati melalui metode penelitan hukum. Penelitian hukum mempunyai banyak ragam dan sifat seperti ekploratif, diskrptif, longitudinal dan berdasarkan bidang ilmu hukum yang ingin diteliti. Penelitian ini menggunakan metode yuridis normative-empiris. Metode yuridis normative merupakan prosedur penelitian ilmiah untuk menemukan kebenaran berdasarkan logika 
keilmuan hukum dari sisi normatifnya (Wulansari, 2017). Sementara penelitian normatif, menurut Purnadi Purbacaraka dan Surdjono Sukanto, "gigevens van het recht" yakni data hukum yang sudah tersedia atau juga hukum positif, yakni penelitilah kepustakaan, berupa buku-buku dan peraturan perundang-undangan lainnya sebagai hukum positif. Kata lain dari metode normatif juga disebut metode doktrilenial (Soerdjono Soekanto, 1985). Sedang metode penelian empiris, penelitian yang menggambarakan adanya konflik atau tidak dalam masyarakat atau adanya putusan hukum atas konflik hukum yang di bawa ke pengadilan hingga mendapatkan putusan final.

Terjadinya permohonan oleh salah satu pimpinan perusahaan penerbitan, menjadikan konflik hukum antara DP dengan penggugat. Oleh karenanya, metode penulisannya menggunakan gabungan yuridis normative-empiris, sehingga penulis tidak hanya sekedar mengumpulkan data primer, berupa buku, jurnal, undang-undang dan peraturan Dewan Pers (DP). Tetapi juga meneliti putusan (MK). No 51 Tahun 2018. Pada titik tersebut masih ada ruang untuk dianalisis, mengapa DP membuat aturan badan hukum harus berbentuk PT dan Apa dampak dari peraturan itu terhadap anggota masyarakat yang mempunyai usaha pers di luar badan hukum PT setelah keluarnya Putusan MK No 51/PUU-XVI/2018. Semua bahan dikumpulkan, kemudian disatukan dalam tautan narasi, kemudian dianalisis untuk mendapatkan gambaran, peraturan DP yang dikuatkan oleh putusan MK itu awalnya merupakan doktrin hukum tetapi dikuatkan MK sehingga sebagai peneguhan hukum positif, yang sekaligus belum mengakomodir hukum progesif yang saat ini sedang tumbuh diberbagai diskursus para ahli hukum di Indonesia.

\section{Hasil dan Pembahasan}

Sejak 500 tahun sebelum masehi, orang -orang Germania sudah mendiskusikan soal hukum. Hukum sangat dibutuhkan oleh masyarakat setempat karena tanpa ada aturan atau hukum niscaya kehidupan di masayarakat sering terjadi chaos, atau akan terjadi penindasan satu dengan kelompok lainnya.

Isilah "Franka Salis, atau lex salica" sudah sering diucapkan oleh para tokoh masyarakat Eropa khususnya Germania, karena adanya hukum diyakini dapat membuat keteraturan hidup dalam masyarakat. Oleh L. J. Van Apeldoorn disebutkan, tujuan hukum antara lain untuk mengatur pergaulan hidup masyarakat secara damai, hukum menghendaki perdamain, keteraturan, kepastian dan baru akan muncul keadilan (LJ van Apeldorn, 2011).

Dua bentuk keadilan dalam literatur Arestoteles, keadilan distributif dan keadilan comutatif. Distributif memberikan bagian kepada seseorang sesuai dengan jasa yang dikerjakan atau sesuai dengan tanggungjawab yang dipikul. Sedang keadilan comutatif, keadilan sama rata dari masing-masing anggota masyarakat, misalnya, pemberian jumlah pagu kredit kepada pedagang kecil, masing-masig diberi jumlah pagu pinjaman yang sama, tanpa mempertimbangkan jasa dari masing-masing anggota. Arestoteles 
menjelaskan soal dua bentuk keadilan, sehingga ada yang berpikir esensi hukum bagi Arestoteles adalah keadilan.

Tujuan hukum yang lain dapat dikutip dari pemikiran Mochtar Kusumaadmadja (Shidarta, 2020). Mochtar menyamakan fungsi hukum dan tujuan hukum. Jika seseorang ingin melakukan usaha dibidang jasa dan perdagangan misalnya, maka dibutuhkan kepastian dalam pengurusan ijin, maupun tempat untuk usaha itu.

Hukum dapat mengatur prosedur dan jumlah biaya yang harus dibayarkan kepada negara untuk mendapat ijin usaha dan tepat usahanya. Sementara jika seseorang akan melindungi harta dan kekayaannya, dibutuhkan situasi yang tertib dan damai. Tidak terjadi caus atau penjarahan, maka hukum dapat mengatur ketertiban agar orang tidak mudah melanggar aturan karena akan ada sanksi tegas yakni administrasi hingga penjara. Maka hal itu oleh Mochtar disebutnya fungsi hukum tak jauh beda dengan tujuan hukum.

Kemudian bagaimana dengan tujuan hukum untuk mencari keadilan? dalam teori hukum positif keadilan akan diperoleh jika semua itu di dasarkan pada hukum dan pasal-pasal yang telah disusun oleh para pembuat undang-undang yakni DPR dan pemerintah. Namun dalam perkembangannya, para ahli hukum kini mulai mengkritisi, keadilan tidak akan diperoleh hanya melalui pengadilan yang hanya mendasarkan pada pasal-pasal dalam hukum itu.

Tuntutan sebagian masyarakat agar para hakim mengadili suatu tuntutan tidak hanya sekedar meligitimasi tuntutan penuntut umum, tetapi juga seorang hakim wajib menggali keadilan yang tidak hanya di dalam pasal-pasal namun juga di dalam norma masyarakat dan keyakinan dalam hakim itu sendiri.

Hakim adalah independent, dimana putusannya tidak dapat diintervensi oleh seseorang, atau kekuasaan mana-pun. Kekuasaan kehakiman yang independen, atau merdeka salah satu syarat tumbuh dan berkembangannya demokrasi di suatu Negara (Supraptiningsih, 2019). Indonesia juga menganut sistem peradilan yang independent. Pasal 24 ayat (1) UUD RI menyebutkan: "Kekuasaan Kehakiman merupakan kekuasaan yang merdeka untuk menyelenggarakan peradilan guna menegakkan hukum dan keadilan".

Dengan demikian jelaslah, Indonesia menganut sistem demokrasi karena salah satu ciri utamanya, sistem peradilan terbuka dan tidak dapat diinentervensi oleh siapapun termasuk oleh kekuasaan. Hal itu berbeda dengan negara sosialis komunis dan totaliter dimana kekuasaan pengadilan dibayang-bayangi oleh campur tangan kekuasaan, atau para hakim tinggal melegmitasi dari kemauan kekuasaan. Guna meneguhkan sistem peradilan yang fair, DPR bersama pemerintah membuat UU No 48 Tahun 2009 tentang kekuasaan kehakiman. Dimana salah satu poinnya memberikan kebebesan hakim untuk memutus suatu kasus, termasuk kasus sengeketa peraturan Perundang-undangan, diputus secara indepenen agar nilai keadilan dapat dirasakan oleh para pencari keadilan. Pasal 28 UU kehakiman Tahun 2004 menyebutkan: 
"Hakim wajib menggali, mengikuti, dan memahami nilai-nilai hukum dan rasa keadilan yang hidup dalam masyarakat. (2) Dalam mempertimbangkan berat ringannya pidana, hakim wajib memperhatikan pula sifat yang baik dan jahat dari terdakwa".

Pasal tersebut merupakan terjemahan dari Pasal 24 UUD tentang kemerdekaan seorang hakim, yang juga di konkritkan lagi pada Pasal 1 UU kehamkiman. Hakim wajib menggali hukum dan keadilan di dalam masyarakat.

Hakim juga diharuskan untuk tidak tunduk pada pasal-pasal yang disodorkan oleh penunut umum, (Kejaksaan Agung) namun seorang hakim diberi kekuasaan seluasluasnya untuk mempertimbangkan nilai keadilan yang akan dijatuhkan dalam suatu putusan. Hal itu berarti kekuasaan kehakiman independent dan terbuka, bebas dari intervensi manapun.

\section{Dewan Pers Sebagai Lembaga Negara}

Pengertian lembaga negara dalam Kamus KBBI online disebutkan, "Asal mula yang akan menjadikan sesuatu". Lembaga juga dapat dimaknai bentuk atau acuan (Kemendikbud, 2019). Apapun Namanya, pada intinya sebuah lembaga mempunyai tugas dan fungsi untuk melaksanakan sesuatu atas perintah Undangundang maupun peraturan di bawahnya. Jemly Asshiddiqie, menyebutkan, dalam bahasa Belanda dikenal, staat sorgaan, bahasa Inggis, dimaknai political institution, dan di Indonesia lebih dikenal lembaga-lembaga negara, badan negara, atau organ negara yang juga dapat disebut sebagai dewan merujuk ke kata lembaga (Akbar, 2013). Dalam hukum ketatanegaraan Indonesia, lembaga negara dapat di klasifikasi menjadi tiga klaster, yakni lembaga tinggi negara, lembaga negara dan lembaga negara yang dibuat di bawah Undang-undang.

Lembaga tinggi negara dalam pembentukannya sudah termaktub dalam UUD 1945 seperti Badan Pemeriksaan Keuangan (BPK) terdapat dalam Pasal 23 E ayat 1 menyebutkan, "Untuk memeriksa pengelolaan dan tanggungjawab tentang keuangan negara diadakan saatu Badan Pemeriksaan Keuangan yang bebas dan mandiri." Dengan demikian, BPK lembaga independent yang tak dapat diientervensi oleh lembaga lainnya untuk melakukan pengawasan pengelolaan keuangan negara, dan lembaga itu atas perintah dari UUD 1945.

Lembaga atas perintah UUD juga dapat ditemukan dalam Pasal 7A ayat (3-5) UUD 1945 tentang keberadaan Mahkamah Konstitusi (MK) yang dapat mengadili pemberhentian Presiden atas usulan 2/3 dari Anggota Dewan. Sementara lembaga yang dibuat oleh Undang-undang antara lain Dewan pers (DP) dibuat lewat UU No 40 Tahun 1999 pada Bab V tentang Dewan Pers. Pasal 15 ayat (1-7) memberi tugas dan fungsi Dewan Pers, sebagai tindak lanjut dari tugas pemerintah.

Sedang lembaga yang dibuat bukan dari UUD dan UU dapat juga dibuat oleh Presiden seperti Badan Keamanan Laut (Bakamla), Badan Penanggulangan Bencana dan badan lainnya. Pada intinya, Dewan Pers lembaga dibuat atas perintah UU pers. Dengan demikian, lembaga atau dewan yang dibuat oleh staat sorgaan, atau oleh pemerintah bersama DPR dapat membuat peraturan lanjutan terkait dengan tugas pokoknya sebagai penjaga demokrasi dibidang pers. 


\section{Dewan Pers Berhak Membuat Peraturan}

Berhakkah Dewan Pers membuat peraturan? Sebagai lembaga yang dibuat oleh Undang-undang dan mempunyai fungsi dan tugas utamanya, dibenakan untuk membuat peraturan terkait dengan tugas pokok yang dimandatkan oleh UndangUndang itu.

Undang-undang ada penjelasan, dan jika dalam suatu pasal dimungkinkan untuk ditindak lanjuti, biasanya diatur lebih lanjut melalui peraturan pemerintah. Khusus dalam UU No 40 Tahun 1999 tentang Pers, sampai saat ini tidak lahir peraturan pemerintah sebagai tindak lanjut dari UU itu. Oleh karenanya, DP membuat peraturan dimaksudkan bukan sebagai pengganti peraturan pemerintah tetapi lebih menegaskan fungsinya sebagai penata perusahaan pers dan ikut meningkatkan kualitas wartawan. Zaid Afif menyebutkan, dalam ketatanegaraan Indonesia, dibenakan lembaga negara membuat peraturan lebih lanjut terkait dengan tugas pokoknya. UUD 1945 bersifat singkat dan supel, hanya terdiri dari 37 pasal ditambah 4 pasal Aturan Peralihan dan 2 ayat aturan tambahan.

Oleh karenanya, agar sistem UUD tidak ketinggalan zaman, dan jangan sampai membuat Undang-Undang Dasar yang lekas usang, ketatanegaraan Indonesia dimungkinkan lembaga negara membuat. Peraturan Perudang-undangan salah satu bentuk kebijaksanaan tertulis yang bersifat pengaturan (relegen) (Afif, 2018).

Pembuatan peraturan perundang-undangan itu dari MPR hingga Direktorat Jenderal/Pimpinan Lembaga Pemerintah Non Departemen (LPDN) pada lingkup nasional dan lingkup kepala daerah tingkat I dan tingkat II. Dengan demikian, legalitas lembaga yang dimiliki karena dibuat oleh UU, DP sesuai dengan kewenangannya mengeluarkan Surat Keputusan No 4/Peraturan DP/III/2008 tentang Standar Perusahaan Pers.

Salah satu poinnya antara lain, perusahaan pers badan hukum Indonesia yang menyelenggarakan usaha pers meliputi perusahaan media cetak media elektronik, dan kantor berita, serta perusahaan media lainnya yang secara khusus menyelenggarakan, menyiarkan atau menyampaikan informasi secara tegas. Peraturan itu kemudian ditindak lanjuti, himbauan Dewan Pers kepada seluruh media yang akan mendaftarkan perusahannya, khususnya pers yang bersifat umum dan komersial diwajibkan menggunakan Perseroan Terbatas. (PT) Artinya jika perusahaan pers akan melakukan pendaftaran ke DP tidak dibenarkan dan diterima jika lembaganya bukan PT seperti CV, Koperasi dan Yayasan.

Bagir Manan, menyebutkan, kemerdekaan pers setelah pasca reformasi 1998 tidak dimaksudkan membuat usaha pers sebebas-bebasnya tanpa ada batasan. Setelah adanya UU No 4 Tahun 1999 usaha penerbitan tidak lagi membutuhkan Surat ijin Usaha Penerbitan (SIUP), namun di media yang menggunakan sarana gelombang seperti TV dan radio masih menggunakan ijin karena keterbatasan frekuensi milik negara untuk kepentingan publik. Di luar TV, Radio dan SIUP bermuncullah usaha yang bergerak dibidang pers lewat web dan lain-lainnya. 
Sehingga banyaknya sarana pers yang berbentuk web itu diperlukan penataan dibidang kelembagaan pers (Manan \& Harijanti, 2016).

Tahun 2020 jumlah perusahan pers berbasis media siber, sudah terdata dan mendaftar ke Dewan pers lebih dari 1.561 perusahaan pers. Tahun 2014 jumlah media siber hanya 211 perusahaan pers. Jumlah perusahaan pers yang belum mendaftar dan belum di data (ferifikasi) oleh Dewan Pers, tentunya lebih besar dari jumlah itu, karena untuk mendaftarkan perusahaan ke DP selain melalui online, juga persyaratan yang cukup ketat, seperti Nomor Waib Pajak (NPWP), berbadan hukum (PT), memuat penaggungjawab dan alamat secretariat perusahaan pers itu (Fuqoha, Firdausi, \& Sanjaya, 2019). Data Pers Nasonal 2014 juga menyampaikan, sejumlah 567 media cetak, 1.166 stasiun radio, dan 394 stasiun televisi. Jumlah perusahaan pers baik dari rado, televisi dan media cetak mengalami kenaikan dari tahun sebelumnya (Fuqoha et al., 2019).

\section{Study Kasus Putusan MK No 51 Tahun 2018}

Mahkamah Kosntitusis (MK) telah mengadili perkara pada tingkat pertama dan terakhir (final and binding) atas pengujian UU No 40 Tahun 1999 tentang Pers terhadap UUD RI 1945 yang diajukan oleh Nama Ferdinan Holomoan Lumban Tobing SE dengan Jabatan Direktur CV Swara Resi Perusahaan Penerbit. Alamat J1. Apel Blok U Nomor 1 Mekarsari Permai Cimanggis Depok 16952. Adapun Duduk Perkaranya dapat diresume sebagai berikut: Pemohon telah mendaftarkan gugatannya ke MK dan diterima dan dicacat pada permohnan No 51/PUUXVI/2018. Pemohon merasa dirugikan hak-hak konstitusionalnya atas Pasal 1 ayat (2) Pasal 9 ayat (2) dan Pasal 18 ayat (3) UU Pers yang oleh pemohon dinilai mengurangi hak konstitusionalnya untuk melakukan usaha sesuai Paal 33 ayat (4) dan Pasal 27 ayat (2) dan Pasal 28 D dan F. UUD 1945.

Dewan Pers secara khusus mengeluarkan Surat Edaran (SE) No 01/SEDP/!/2014 tentang Pelaksanaan UU Pers dan Standar Perusahaan Pers yang diedarkan ke seluruh wilayah nasonal pusat dan daerah, akibatnya, perusahaan penerbitan dilarang melakukan peliputan jurnalistik yang dilindungi hukum khususunya dalam kebebasan pers termasuk untuk mencari atau mendapatkan iklan dan kegiatan yang terkait dengan pers. Bahkan DP juga memberikan sanksi pidan terhadap perusahaan pers yang tidak berbadan hukum.

Terhadap keberatan pemohon, MK dalam pertimbangannya, pemohon tidak secara sepesifik mencantumkan sebagai Direktur CW Swara Resi Perusahaan Penerbitan Pers, tetapi hanya sebagai Direktur CV Swara Resi yang bergerak dalam bidang Penerbitan, sesuai akta notaris yang dibuat pada 28 November 2002.

MK dalam pertimbangannya juga menyampaikan, wadah untuk menyelenggarakan perusahaanpers berdasarkan Pasal 1 angka 2 juncto Pasal 9 ayat (2) UU Pers, perusahaan pers berbentuk badan hukum Indonesia. Ketentuan tersebut dikuatkan oleh Surat Edaran DP No 01/SE-DP/I/2014 tentang Pelaksanaan UU Pers dan Standar Perusahaan Pers yang menyatakan, perusahaan pers harus berbadan hukum Indonesia berbentuk PT atau badan hukum lainnya yaitu Yayasan 
atau koperasi. Dengan demikian setiap orang ingin mendirikan perusahaan pers harus menyebut secara khusus dan tidak dapat dicampur dengan usaha lainnya, selain dibidang pers.

Ketentuan itu berlaku secara umum, yakni setiap orang warga negara Indonesia tanpa kecuali yang ingin mendirikan perusahaan pers harus berbadan hukum Indonesia, aquo, sehingga MK menilai tidak melanggar terhadap Pasal $28 \mathrm{~J}$ ayat (2) UUD 1945. Setelah MK mempertimbangkan secara rinci dan wajar, dalam Amar Putusannya menyebutkan: Mengadili, menyatakan permohonan pemohon tidak dapat diterima. Putusan itu dibacakan oleh Ketua Anwar Usman, dan empat anggota, Aswanto, rief Hidayat, Manahan MP Sitompul, Suhartoyo, pada hari Kamis, tanggal 25 Oktober 2018.

Dalam Putusan MK dapat disarikan, pertama, pemohon mempunyai legal standing dan hak konstitusional sebagai pemohon, namun tidak secara spesifik menyebutkan sebagai Direktur Perusahaan Swara Resi, Penerbitan yang bergerak dibidang Pers, Kedua, SE No 01/SE-DP/I/2014 sebagai pelaksanaan Pasal 9 ayat (2) UU 40 Tahun 1999 tentang pers yang belaku secara umum terhadap setiap orang warga negara Indonesia ingin bergerak dibidang pers secara khusus dalam akta pendiriannya menyebutkan hal itu, Ketiga, MK menilai peraturan dari DP yang dimohnan, tidak bertentangan Pasal 28 J UUD 1945.

\section{Kesimpulan}

Dari uraian tema Perusahan Pers wajib berbadan hukum Indonesia, utamanya menggunakan Perseroan Terbatas (PT) jika usaha itu dimaknai sebagai usaha komersial, dapat disimpulkan:

Pertama, Indonesia termasuk salah satu negara yang mengembangkan demokrasi yang ditandai dengan independensi lembaga pengadilan dan kebebasan pers. Kebebasan pers sesuai amanat reformasi telah dituangkan melalui UU No 40 Tahun 1999 tentang Pers. Pasal 9 ayat (1) dan (2) menyebutkan, Setiap warga negara Indonesia dan negara berhak mendirikan perusahaan pers. Setiap perusahaan pers harus berbentuk badan hukum Indonesia. Saat orde lama dan orde baru berkuasa, tidak semua warga negara bebas mendirikan perusahaan pers karena ada ijin penerbitan (SIUP) yang dikeluarkan oleh pemerintah. Adanya Pasal 9 ayat (1) dan (2), surat ijin penerbitan tidak diperlukan lagi, sehingga perusahaan pers berkembang cukup pesat hingga ribuan perusahaan pers pasca reformasi itu. Pasal 15 UU Pers mengatur peran dan fungsi Dewan Pers. Untuk mengatur perusahaan pers yang cukup banyak, DP mengeluarkan Peraturan No.4/DP/III/2008 tentang Standarisasi Perusahaan Jo Surat Edaran DP No 01/SE DP/I/2014 Pelaksanaan UU Pers dan Standarsasi Perusahaan Pers.

Kedua, Peraturan DP yang dimaksudkan menata perusahaan pers dan melindungi pekerja jurnalistik agar dapat bekerja secara profesional dan mendapatkan perlindungan kesejahteraan, dilakukan uji materi dari salah seorang pimpinan perusahaan penerbit.

Ketiga, dari permohonan uji materi ke MK terhadap Pasal 9, ayat (1) dan (2) Pasal 15 UU Pers Jo Peraturan DP No 4/DP/III/2008 Jo SE No 01/SE DP/1/2014, oleh 
seorang direkur perbitan, ditolak oleh MK karena dinilai permohonanya tidak spesifik sebagai perusahaan per. Selain Dewan Pers, sebuah lembaga yang mempunyai kewenangan untuk membuat Peraturan Perundang-undangan sesuai dengan tugas pokok dan fungsinya. 


\section{BIBLIOGRAFI}

Abhimantara, Ida Bagus. (2019). Kedudukan Persekutuan Komanditer (Commanditaire Venootschap) Sebagai Corporate Guarantee. Notaire, 2(3), 359-372. Google Scholar

Afif, Zaid. (2018). Pembentukan Peraturan Perundang-undangan Berdasarkan Pancasila dan UUD NKRI. Dialog, 7 (September), 1-15. Google Scholar

Akbar, Patrialis. (2013). Lembaga-Lembaga Negara Menurut UUD NRI Tahun 1945. Penerbit Sinar Grafika. Google Scholar

Bo'a, Fais Yonas. (2020). Peranan Mahkamah Konstitusi Dalam Menjaga Tegaknya Cita Hukum (Rechts Idee) Pancasila Dalam Bernegara. Arena Hukum, 13(1), 97116. Google Scholar

Budiardjo, Miriam. (2010). Dasar-Dasar Ilmu Politik, edisi revisi, cet. IV. Jakarta: Gramedia Pustaka Utama. Google Scholar

Faizal, Liky. (2016). Problematika Hukum Progresif Di Indonesia. Ijtimaiyya: Jurnal Pengembangan Masyarakat Islam, 9(2), 1-24. Google Scholar

Fuqoha, Fuqoha, Firdausi, Indrianti Azhar, \& Sanjaya, Arga Eka. (2019). Perlindungan Hukum Terhadap Intervensi Pemberitaan Dalam Kerangka Kemerdekaan Pers Nasional. Ajudikasi: Jurnal Ilmu Hukum, 3(1), 75. Google Scholar

Kemendikbud. (2019). KBBI - Kamus Besar Bahasa Indonesia. Kamus Besar Bahasa Indonesia. Google Scholar

LJ van Apeldorn. (2011). Pengantar Ilmu Hukum. Jakarta: Pradnya Paramita Jakarta. Google Scholar

Manan, Bagir, \& Harijanti, Susi Dwi. (2016). Artikel Kehormatan: Konstitusi dan Hak Asasi Manusia. Padjadjaran Journal of Law, 3(3), 448-467. Google Scholar

Shidarta, Shidarta. (2020). Bernard Arief Sidharta: Dari Pengembanan Hukum Teoretis ke Pembentukan Ilmu Hukum Nasional Indonesia. Undang: Jurnal Hukum, 3(2), 441-476. Google Scholar

Soerdjono Soekanto, Sri Mamudji. (1985). Penelitian Hukum Normatif. CV Rajawali. Google Scholar

Supraptiningsih, Umi. (2019). Peradilan Satu Atap Sebagai Perwujudan Kekuasaan Kehakiman Yang Merdeka. Al-Ihkam: Jurnal Hukum Dan Pranata Sosial, 2(2), 291-310. Google Scholar

Wulansari, R. R. Catharina Dewi. (2017). The Role of The Government in The Recognition of Customary Rights to Achieve Economic Development of 
Ketentuan Perusahaan Pers Wajib Berbadan Hukum Perseroan Terbatas (PT) Merupakan Doktrin Hukum yang Berbasis Hukum Positif

Customary Law Communities. Journal of Indonesian Adat Law (JIAL), 1(1), 109145. Google Scholar

\section{Copyright holder:}

Yusuf Ms (2021)

First publication right:

Syntax Literate: Jurnal Ilmiah Indonesia

This article is licensed under:

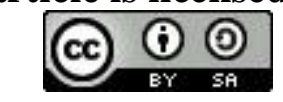

